\title{
PENCIPTAAN INFORMASI KERUANGAN WAKTU MUSIM HUJAN DAN KEMARAU UNTUK MENGANTISIPASI BENCANA BANJIR DAN KEKERINGAN
}

\author{
Spatial Information Creation of Rainy and Dry Seasons Time to Anticipate Flood and \\ Drought
}

Iskandar Muda Purwaamijaya Kemristekdikti/ Program Studi Teknik Sipil-FPTK-Universitas Pendidikan Indonesia
email: ais_imp@ yahoo.com ; aisiskandarmudap@ gmail.com

\begin{abstract}
The study purpose (1) design a spatial information conceptual model during the rainy season and dry season to anticipate floods and droughts (2) create a functional model based conceptual model, (3) implement functional model. Solving the problem method is descriptive and analytical techniques used spatial analysis and matrix. The study conclusion (1) the conceptual model results matrix analysis concluded basic map that used to be a small-scale and refers to the raw information used BPLHD's, (2) the functional model results matrix analysis concludes the spatial information components number to be presented is the 8 components of point, four components of line, 8 components of polygon and 12 components of spatial information annotation, (3) the model implementation results matrix analysis produces unity polygon graphics information to the boundary of the village, sub-district, county, the provincial boundaries, bodies of water catchment areas, wind roses, land use stored in the record and file levels. Unity of graphic information point for the station rainfall and water bodiesthat is stored in the record and file levels. Unitary information line for a water body, isohyets, isobars and isotemp stored in the record and file levels.
\end{abstract}

Keywords: information, spatial, rain, floods, droughts

\begin{abstract}
Abstrak
Tujuan penelitian (1) merancang model konseptual informasi keruangan waktu musim hujan dan kemarau untuk mengantisipasi bencana banjir dan kekeringan, (2) membuat model fungsional dari hasil permodelan konseptual, (3) mengimplementasikan permodelan fungsional. Metode pemecahan masalah adalah dengan deskriptif dan teknik analisis yang digunakan analisis keruangan dan matriks. Kesimpulan penelitian (1) model konseptual hasil analisis matrik menyimpulkan peta dasar yang digunakan harus berskala kecil (lingkup Provinsi Jawa Barat) dan merujuk pada informasi baku yang digunakan oleh BPLHD (Badan Pengendalian Lingkungan Hidup Daerah), (2) model fungsional hasil analisis matriks menyimpulkan jumlah komponen informasi spasial yang harus disajikan adalah 8 komponen informasi spasial titik (point), 4 komponen informasi spasial garis (line), 8 komponen informasi spasial area (polygon) serta 12 komponen informasi spasial teks (annotation), (3) implementasi model hasil analisis matrik menghasilkan kesatuan informasi grafis polygon untuk batas desa, batas kecamatan, batas kabupaten, batas provinsi, badan air, catchment area, wind roses, landuse yang disimpan dalam tingkatan record dan file. Kesatuan informasi grafis point untuk stasiun curah hujan dan badan air yang disimpan dalam tingkatan record dan file. Kesatuan informasi line untuk badan air, isohyet, isobar dan isotemp yang disimpan dalam tingkatan record dan file.
\end{abstract}

Kata kunci: informasi, keruangan, hujan, kemarau, banjir, kekeringan

\section{PENDAHULUAN}

Bencana banjir dan kemarau disebabkan oleh curah hujan yang tinggi pada musim hujan dan curah hujan yang rendah pada musim kemarau. Antisipasi yang tepat terhadap musim hujan dan kemarau dapat mengurangi dampak negatif bencana tersebut. Informasi keruangan dibutuhkan untuk memudahkan para pengambil keputusan, masyarakat dan pihak swasta mengantisipasi secara tepat, cepat, mudah 
dan murah. Konsep penyajian informasi keruangan tentang waktu musim hujan dan kemarau untuk mengantisipasi bencana banjir dan kemarau dibutuhkan agar informasi keruangan yang dihasilkan dapat memenuhi kebutuhan para pengguna secara tepat. Fakta di lapangan menunjukkan banyak para pemangku kepentingan kesulitan memperoleh informasi keruangan waktu musim hujan dan kemarau secara cepat, tepat, mudah dan murah.

Pemberdayaan informasi keruangan waktu musim hujan dan kemarau untuk mengantisipasi bencana banjir dan kemarau harus didukung oleh suatu model fungsional untuk mengindentifikasi, menginventarisir dan mengurutkan detail-detail alam dan buatan manusia terhadap resolusi informasi. Kesalahan sistematis dan acak mungkin terjadi terhadap informasi keruangan waktu musim hujan dan kemarau jika permodelan fungsional tidak dilalui. Fakta di lapangan menunjukkan banyak para perancang informasi keruangan yang tidak melakukan tahap permodelan fungsional karena dianggap membuang waktu, tenaga dan biaya.

Implementasi informasi keruangan waktu musim hujan dan kemarau untuk mengantisipasi bencana banjir dan longsor melibatkan komponen-komponen perangkat keras (hardware), perangkat lunak (software), perangkat intelegensia (brainware) dan tenaga kerja (man power). Implementasi keruangan waktu musim hujan dan kemarau untuk mengantisipasi bencana banjir dan longsor membutuhkan suatu system kerja, pendanaan dan sumber daya manusia. Fakta di lapangan menunjukkan banyak para pengambil keputusan dan pemangku kepentingan menganggap informasi keruangan waktu musim hujan dan kemarau untuk mengantisipasi bencana banjir dan kemarau adalah suatu kegiatan yang sederhana dan tidak penting dan tidak membutuhkan suatu perencanaan yang matang.

Tujuan penelitian, yaitu :

- Merancang model konseptual informasi keruangan waktu musim hujan dan kemarau untuk mengantisipasi bencana banjir dan kekeringan,

- Membuat model fungsional dari hasil permodelan konseptual,
- Mengimplementasikan informasi keruangan waktu musim hujan dan kemarau untuk mengantisipasi bencana banjir dan kekeringan.

As-syakur, Nuarsa dan Sunarta (2013) melakukan kajian tentang Pemutakhiran Peta Agroklimat Klasifikasi Oldeman di Pulau Lombok dengan Aplikasi Sistem Informasi Geografi. Kajian menguraikan tentang pemutakhiran peta agroklimat klasifikasi Oldeman di Pulau Lombok berdasarkan data curah hujan terbaru. Metode yang digunakan adalah interpolasi atau ekstrapolasi yang ditindaklanjuti dengan proses overlay tumpang tindih menggunakan aplikasi Sistem Informasi Geografi.

Kementerian Perencanaan Pembangunan Nasional - Badan Perencanaan Pembangunan Nasional Indonesia (BAPPENAS) (2014) menghasilkan Rencana Aksi Nasional Adaptasi Perubahan Iklim (RAN-API) menyatakan bahwa Indonesia sebagai Negara kepulauan terbesar di dunia merupakan salah satu Negara yang paling rentan terhadap dampak negatif perubahan iklim. Model perubahan iklim memprediksi semua wilayah Indonesia akan mengalami kenaikan temperatur meliputi temperatur permukaan laut yang meningkatkan dan mengubah pola serta intensitas curah hujan yang akan meningkatkan risiko banjir dan kekeringan pada musim kemarau.

Wijayanto (2013) melakukan kajian penggunaan system informasi geografis untuk pertanian presisi. Hasil kajian menunjukkan penggunaan SIG dapat dikelompokkan dalam (1) penggunaan SIG untuk penilaian variabilitas, (2) penggunaan SIG sebagai database) pertanian presisi dan (3) penggunaan SIG untuk membuat rekomendasi (prescription).

Moreno, Goyette dan Beniston (2009) dalam artikelnya tentang Impact of climate change on snowpack in the Pyrenees : Horizontal spatial variability and vertical gradients melakukan permodelan ketebalan salju dari data seri di Pyrenees menggunakan data yang diturunkan dari model iklim wilayah HIRHAM pada dua saat periode tahun 1960-1990 dan dua scenario (SRES B2 dan A2) sampai dengan akhir abad ke 21 (2070-2100).

Craglia, Goodchild, Annoni, Camara, Gould, Kuhn, Mark, Masser, Maguire, Liang dan Parsons (2008) dalam artikel tentang 
Next-Generation Digital Earth - A position paper from the Vespucci Iniative for the Advancement of Geographic Information Science menyatakan bahwa artikel merupakan keluaran dari cerminan kerjasama yang dilakukan oleh pemerintah, industry dan kalangan perguruan tinggi berdasarkan inisiatif Vespucci untuk perkembangan dan keberlajutan ilmu informasi geografis.

Dobrowski, Abatzoglou, Greenberg dan Schladow (2009) dalam artikel tentang How much influence does landscape-scale physiography have on air temperature in a mountain environment ? menyatakan pola waktu dan ruang di sekitar lingkungan pegunungan sangat rumit untuk dikendalikan pada skala synoptic dan landscape system wilayah pegunungan. Pemahaman tentang besaran dan alam pada akibat samping physiographic memiliki implikasi praktis dan teori pada perkembangan serangkaian data temperature digunakan untuk penilaian ekosistem dan kajian dampak perubahan iklim pada wilayah yang memiliki permukaan yang rumit.

Willmott dan Matsuura (2006) dalam artikel tentang On the use of dimensioned measures of error to evaluate the performance of spatial interpolators menyatakan bahwa validasi melintang ruang (spatial cross-validation) dan statistik kesalahan nilai rata-rata (average-error statistics) dilakukan dengan pertimbangan berdasarkan kemampuan untuk menilai berbagai pilihan metode interpolasi ruang. Metodologi validasi melintang sederhana disajikan berikut tiga kemampuan relatifnya, statistik kesalahan digambarkan, yaitu kesalahan akar kuadrat nilai rata-rata (rootmean-square error) (RMSE), kesalahan absolut nilai rata-rata (the mean absolute error) (MAE) dan kesalahan bias nilai ratarata (the mean bias error) (MBE) untuk menggambarkan kinerja cara interpolasi nilai rata-rata (average interpolator performance) yang dilakukan.

Montecinos, Godoy, Salinas, Astudillo dan Lopez (2013) dalam artikel tentang Estimating Spatial Distribution of Air Temperature from Meteorological Stations Using Atmospheric Model menyatakan bahwa kebutuhan prosedur perencanaan pertanian memasukkan perhitungan keadaan meteorologis. Kerapatan stasiun meteorologis kadang tidak cukup mencakup seluruh potensi lahan tanaman di suatu wilayah karena mahal dan berbiaya tinggi. Artikel menjelaskan tentang metodologi untuk memperkirakan temperatur cuaca rata-rata terbesar dan terkecil di wilayah perkebunan menggunakan daftar data pada suatu tanah atau pada stasiun meteorologis yang terbatas. Prosedur berdasarkan pada permodelan skala menengah yang mencakup peubah meteorologis terhadap persebaran dalam ruang data synoptic dan karakteristik lokal yang ditetapkan.

\section{METODE PENELITIAN}

Penelitian dilakukan dari Bulan April 2015 sampai dengan Bulan November 2015 selama 8 bulan. Penelitian dilakukan di Kabupaten Bandung Provinsi Jawa Barat.

Metode penelitian dilakukan dengan metode deskriptif. Penahapan penelitian disajikan pada gambar 1 bagan alur penelitian (fishbone diagram)

Subjek penelitian adalah para dosen peneliti dari program studi Teknik Sipil FPTK UPI Bandung yang didukung para mahasiswa Teknik Sipil FPTK UPI yang sedang menyelesaikan tugas terstruktur mata kuliah Rekayasa Lingkungan, AMDAL dan Metodologi Penelitian, kerja praktek di bidang bangunan air dan tugas akhir/skripsi keteknikan bidangan pengembangan sumber daya air. 
Pengembangan Kompetensi

Penciptaan Informasi Keruangan

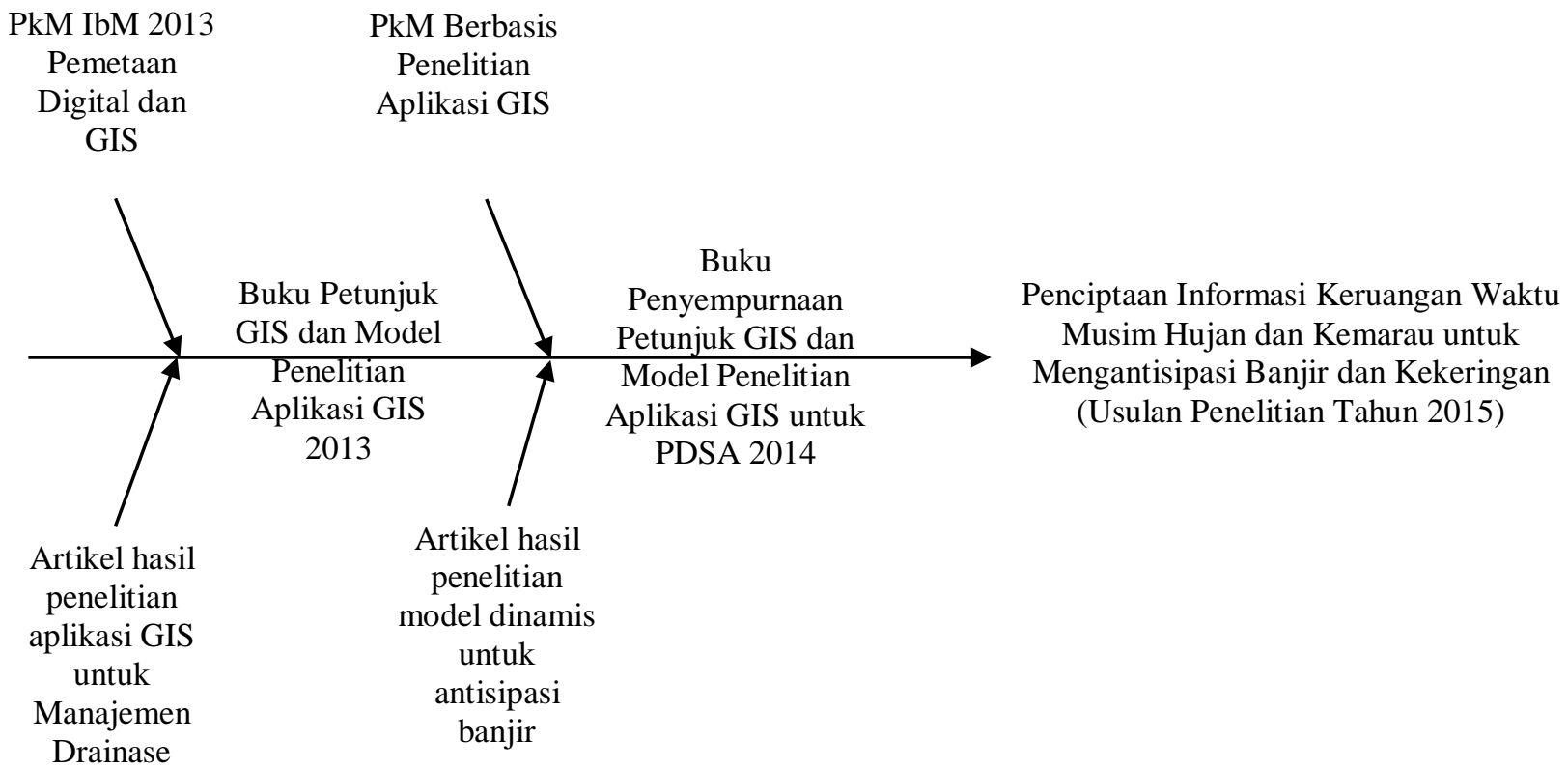

Pengembangan Kompetensi

Pengembangan Sumber Daya Air

Gambar 1. Bagan Alur Penelitian (fishbone diagram)

Instrumen pengumpul data adalah lembar observasi kegiatan di lapangan, instrument pengukur curah hujan debit banjir serta instrument survey dan pemetaan.

Rancangan penelitian diawali dengan permodelan konseptual yang disusun dari hasil identifikasi kebutuhan para pengguna informasi keruangan di lapangan. Rancangan penelitian permodelan konseptual berbentuk matriks yang menginventarisasi informasi detail alam dan buatan manusia dalam ruang yang dibutuhkan dalam pengembangan sumber daya air pada resolusi skala kecil, sedang dan besar oleh instansi PSDA, BPN, BPLHD, BAPPEDA.

Rancangan penelitian dilanjutkan dengan permodelan fungsional yang diperoleh dari hasil permodelan konseptual. Rancangan penelitian permodelan fungsional berbentuk matriks yang memasukkan komponen-komponen prioritas berdasarkan urutan informasi detail alam dan buatan manusia dalam pengembangan sumber daya air terhadap informasi grafis (area, garis dan titik) serta informasi atribut (numeris, string, Boolean dan date).
Implementasi hasil permodelan fungsional yang berbentuk matriks berupa system penamaan dan lokasi tempat penyimpanan informasi dalam data base fisik (folder, file, record) pada tahap pemasukan data, pengolahan data dan pencetakan hasil analisis keruangan. Pemasukan data terdiri dari dua kegiatan, yaitu pekerjaan digitasi base map dan pemasukan data statistik ke dalam data base terkait dengan hasil digitasi peta. Pengolahan data berupa kegiatan analisis statistik deskriptif dan analisis keruangan berupa operasi overlay - tumpang tindih informasi dan pembuatan peta tematik titik dan area yang dibedakan dalam ukuran serta gradasi warna.

\section{HASIL DAN PEMBAHASAN}

\section{Hasil Permodelan Konseptual}

Informasi-informasi yang dimuat dalam matrik model konseptual penciptaan informasi keruangan waktu musim hujan dan kemarau untuk mengantisipasi bencana banjir dan kekeringan dikelompokkan menjadi : 
- Komponen informasi spasial, yang terdiri dari batas desa, batas kecamatan, batas kabupaten, batas provinsi, stasiun curah hujan, badan air, catchment area, isohyet, isotemp, isobar, wind roses dan land use. Komponen informasi spasial diperoleh dari standar-standar nasional dan internasional yang digunakan oleh lembaga-lembaga kompeten di dalam dan di luar negeri.

- Resolusi informasi spasial, yang terdiri dari skala kecil, skala sedang dan skala besar. Resolusi informasi spasial diperoleh dari standar-standar nasional dan internasional yang digunakan oleh lembaga-lembaga kompeten di dalam dan di luar negeri.

- Pengguna informasi spasial, yang terdiri dari BPS (Badan Pusat Statistik) Provinsi Jawa Barat, BAPEDA (Badan Perencana Daerah) Provinsi Jawa Barat, BMKG (Badan Meteorologi, Klimatologi dan Geofisika) Provinsi
Jawa Barat dan BPLHD (Badan Pengendali Lingkungan Hidup Daerah) Provinsi Jawa Barat. Pengguna informasi spasial diperoleh dari tahap awal pembangunan data base spasial musim hujan dan kemarau, yaitu identifikasi kebutuhan pengguna informasi keruangan waktu musim hujan dan kemarau untuk mengantisipasi bencana banjir dan kekeringan.

Permodelan konseptual dibuat untuk memperoleh informasi resolusi peta dasar (base map) yang akan digunakan serta lembaga terpilih yang paling mengakomodasi komponen informasi spasial terbanyak menyajikan informasi keruangan waktu musim hujan dan kemarau untuk mengantisipasi bencana banjir dan kekeringan. Matrik model konseptual penciptaan informasi keruangan waktu musim hujan dan kemarau untuk mengantisipasi bencana banjir dan kekeringan disajikan pada tabel 1 .

Tabel 1. Matriks model konseptual penciptaan informasi keruangan waktu musim hujan dan kemarau untuk mengantisipasi bencana banjir dan kekeringan (rancangan)

\begin{tabular}{|c|c|c|c|c|c|c|c|}
\hline \multirow[b]{2}{*}{$\begin{array}{l}\text { Komponen Informasi } \\
\text { Spasial }\end{array}$} & \multicolumn{3}{|c|}{ Resolusi } & \multicolumn{4}{|c|}{ Pengguna Informasi } \\
\hline & $\begin{array}{l}\text { Skala } \\
\text { kecil }\end{array}$ & $\begin{array}{r}\text { Skala } \\
\text { sedang }\end{array}$ & $\begin{array}{l}\text { Skala } \\
\text { besar }\end{array}$ & $\begin{array}{c}\text { BPS } \\
\text { Provinsi }\end{array}$ & $\begin{array}{l}\text { BAPEDA } \\
\text { Provinsi }\end{array}$ & $\begin{array}{c}\text { BMKG } \\
\text { Provinsi }\end{array}$ & $\begin{array}{l}\text { BPLHD } \\
\text { Provinsi }\end{array}$ \\
\hline Batas Desa & - & $\sqrt{ }$ & $\sqrt{ }$ & - & - & - & $\sqrt{ }$ \\
\hline Batas Kecamatan & $\sqrt{ }$ & $\sqrt{ }$ & - & $\sqrt{ }$ & $\sqrt{ }$ & $\sqrt{ }$ & $\sqrt{ }$ \\
\hline Batas Kabupaten & $\sqrt{ }$ & $\sqrt{ }$ & - & $\sqrt{ }$ & $\sqrt{ }$ & $\sqrt{ }$ & $\sqrt{ }$ \\
\hline Batas Provinsi & $\sqrt{ }$ & - & - & $\sqrt{ }$ & $\sqrt{ }$ & $\sqrt{ }$ & $\sqrt{ }$ \\
\hline Stasiun Curah Hujan & $\sqrt{ }$ & $\sqrt{ }$ & $\sqrt{ }$ & - & - & $\sqrt{ }$ & $\sqrt{ }$ \\
\hline Badan Air & $\sqrt{ }$ & $\sqrt{ }$ & $\sqrt{ }$ & - & $\sqrt{ }$ & $\sqrt{ }$ & $\sqrt{ }$ \\
\hline Catchment Area & $\sqrt{ }$ & - & - & - & $\sqrt{ }$ & $\sqrt{ }$ & $\sqrt{ }$ \\
\hline Isohyte & $\sqrt{ }$ & $\sqrt{ }$ & - & - & $\sqrt{ }$ & $\sqrt{ }$ & $\sqrt{ }$ \\
\hline Isobar & $\sqrt{ }$ & $\sqrt{ }$ & - & - & $\sqrt{ }$ & $\sqrt{ }$ & $\sqrt{ }$ \\
\hline Isotemp & $\sqrt{ }$ & $\sqrt{ }$ & - & - & $\sqrt{ }$ & $\sqrt{ }$ & $\sqrt{ }$ \\
\hline Windroses & $\sqrt{ }$ & $\sqrt{ }$ & - & - & $\sqrt{ }$ & $\sqrt{ }$ & $\sqrt{ }$ \\
\hline Landuse & $\sqrt{ }$ & $\sqrt{ }$ & $\sqrt{ }$ & - & $\sqrt{ }$ & $\sqrt{ }$ & $\sqrt{ }$ \\
\hline Jumlah & 11 & 10 & 4 & 3 & 10 & 11 & 12 \\
\hline
\end{tabular}

Kesimpulan : Peta dasar (base map) berskala (resolusi) kecil dan detail BPLHD

\section{Hasil Permodelan Fungsional}

Informasi-informasi yang dimuat dalam matrik model fungsional penciptaan informasi keruangan waktu musim hujan dan kemarau untuk mengantisipasi bencana banjir dan kekeringan dikelompokkan menjadi :

- Komponen informasi spasial, yang terdiri dari batas desa, batas kecamatan, batas kabupaten, batas provinsi, stasiun curah hujan, badan air, catchment area, isohyet, isotemp, isobar, wind roses dan land use. Komponen informasi spasial diperoleh dari standar-standar nasional dan internasional yang digunakan oleh lembaga-lembaga kompeten di dalam dan di luar negeri.

- Kesatuan informasi grafis, yang terdiri dari titik (point), garis (line), area (polygon) dan teks (annotation). Kesatuan informasi grafis diperoleh dari 
referensi-referensi tentang GIS (geographic information system) yang bersumber dari dalam dan luar negeri.

Permodelan konseptual dibuat untuk memperoleh informasi jumlah informasi grafis titik, garis, area dan teks yang digunakan untuk menyajikan komponen informasi keruangan waktu musim hujan dan kemarau untuk mengantisipasi bencana banjir dan kekeringan. Matrik model fungsional penciptaan informasi keruangan waktu musim hujan dan kemarau untuk mengantisipasi bencana banjir dan kekeringan disajikan pada tabel 2 .

Tabel 2. Matriks model fungsional penciptaan informasi keruangan waktu musim hujan dan kemarau untuk mengantisipasi bencana banjir dan kekeringan (rancangan)

\begin{tabular}{ccccc}
\hline Komponen Informasi & \multicolumn{4}{c}{ Kesatuan Informasi Grafis } \\
\cline { 2 - 5 } Spasial & Titik (point) & Garis (line) & Area Polygon & Teks annotation \\
\hline Batas Desa & $\sqrt{ }$ & - & $\sqrt{ }$ & $\sqrt{ }$ \\
Batas Kecamatan & $\sqrt{ }$ & - & $\sqrt{ }$ & $\sqrt{ }$ \\
Batas Kabupaten & $\sqrt{ }$ & - & $\sqrt{ }$ & $\sqrt{ }$ \\
Batas Provinsi & $\sqrt{ }$ & - & $\sqrt{ }$ & $\sqrt{ }$ \\
Stasiun Curah Hujan & $\sqrt{ }$ & - & - & $\sqrt{ }$ \\
Badan Air & $\sqrt{ }$ & $\sqrt{ }$ & $\sqrt{ }$ & $\sqrt{ }$ \\
Catchment Area & $\sqrt{ }$ & - & - & $\sqrt{ }$ \\
Isohyte & - & $\sqrt{ }$ & - & $\sqrt{ }$ \\
Isobar & - & $\sqrt{ }$ & - & $\sqrt{ }$ \\
Isotemp & - & $\sqrt{ }$ & $\sqrt{ }$ & $\sqrt{ }$ \\
Windroses & - & - & $\sqrt{ }$ & $\sqrt{ }$ \\
Landuse & $\sqrt{ }$ & - & 8 & 12 \\
\hline Jumlah & 8 & 4 & &
\end{tabular}

\section{Hasil Implementasi}

Matrik implemetasi penciptaan informasi keruangan waktu musim hujan dan kemarau untuk mengantisipasi bencana banjir dan kekeringan dikelompokkan menjadi informasi grafis dan atribut/teks. Informasiinformasi grafis yang dimuat dalam matrik implementasi penciptaan informasi keruangan waktu musim hujan dan kemarau untuk mengantisipasi bencana banjir dan kekeringan dikelompokkan menjadi :

- Komponen informasi spasial, yang terdiri dari batas desa, batas kecamatan, batas kabupaten, batas provinsi, stasiun curah hujan, badan air, catchment area, isohyet, isotemp, isobar, wind roses dan land use. Komponen informasi spasial diperoleh dari standar-standar nasional dan internasional yang digunakan oleh lembaga-lembaga kompeten di dalam dan di luar negeri.

- Kesatuan informasi tahap pemasukan data, proses data dan keluaran yang terdiri dari polygon untuk batas desa, batas kecamatan, batas kabupaten, batas provinsi, badan air, catchment area, wind roses dan land use. Line untuk badan air, isohyet, isobar dan isotemp. Point untuk badan air. Kesatuan informasi diperoleh dari referensireferensi tentang GIS (geographic information system) yang bersumber dari dalam dan luar negeri.

- Tingkat penyimpanan tahap pemasukan data, proses data dan keluaran yang terdiri dari record dan file untuk batas desa, batas kecamatan, batas kabupaten, batas provinsi, stasiun curah hujan, badan air, catchment area, isohyet, isobar, isotemp, wind roses dan land use. Tingkat penyimpanan diperoleh dari referensi-referensi tentang GIS (geographic information system) yang bersumber dari dalam dan luar negeri.

Informasi-informasi atribut/teks yang dimuat dalam matrik implementasi penciptaan informasi keruangan waktu musim hujan dan kemarau untuk mengantisipasi bencana banjir dan kekeringan dikelompokkan menjadi :

- Komponen informasi spasial, yang terdiri dari batas desa, batas kecamatan, batas kabupaten, batas provinsi, stasiun 
curah hujan, badan air, catchment area, isohyet, isotemp, isobar, wind roses dan land use. Komponen informasi spasial diperoleh dari standar-standar nasional dan internasional yang digunakan oleh lembaga-lembaga kompeten di dalam dan di luar negeri.

- Jenis-jenis atribut tahap pemasukan data, proses data dan keluaran yang terdiri dari number (angka-angka), string (teks), date (tanggal) dan Boolean (biner) untuk batas desa, batas kecamatan, batas kabupaten, batas provinsi, stasiun curah hujan, badan air, catchment area, isohyet, isobar, isotemp, wond roses dan land use. Jenisjenis atribut diperoleh dari referensireferensi tentang GIS (geographic information system) yang bersumber dari dalam dan luar negeri.

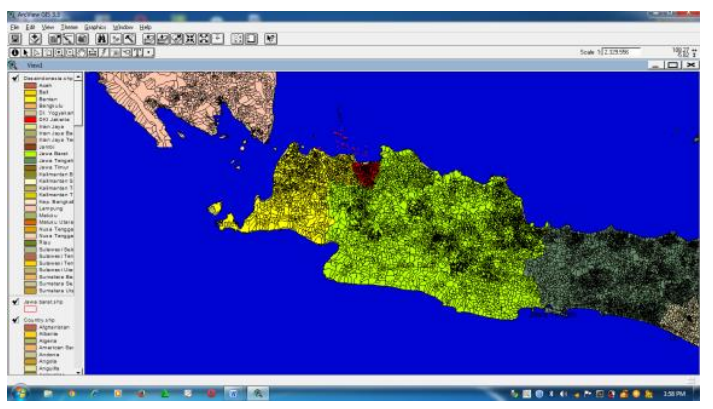

Gambar 2. Peta Desa, Kecamatan, Kabupaten dan Provinsi Hasil Digitasi

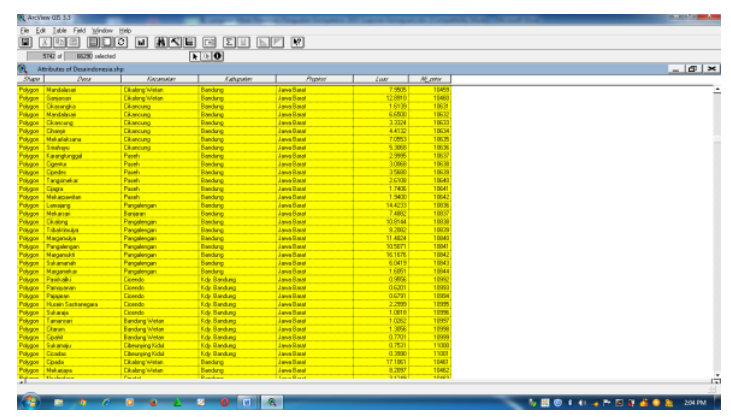

Gambar 3. Database Desa, Kecamatan, Kabupaten, Provinsi Hasil Geocode dan Input Data

\section{Pembahasan Permodelan Konseptual}

Hasil permodelan konseptual menunjukkan bahwa peta dasar (base map) yang digunakan untuk konversi data analog menjadi data digital adalah peta dasar skala kecil (resolusi kecil) yang ruang lingkup wilayahnya adalah Provinsi Jawa Barat. Informasi-informasi grafis dan atribut yang akan digunakan mengacu pada standar yang digunakan oleh BPLHD (Badan Pengendali Lingkungan Hidup Daerah).

\section{Pembahasan Permodelan Fungsional}

Hasil permodelan fungsional menunjukkan bahwa ada 12 informasi spasial yang harus disajikan pada peta-peta tematik musim hujan dan musim kemarau untuk mengantisipasi bencana banjir dan kekeringan. Informasi grafis titik yang disajikan sebanyak 8 buah, informasi garis sebanyak 4 buah, informasi area sebanyak 8 buah dan informasi teks sebanyak 12 buah. Informasi tematik disimpan pada posisi titik, centroid area, segmen garis di sisi kiri dan kanan, penyajian teks sejajar/center/atas/bawah/kiri/kanan features.

\section{Pembahasan Implementasi}

Hasil implementasi menunjukkan jenis informasi grafis yang digunakan meliputi point, line dan polygon untuk menyajikan peta-peta tematik musim hujan dan musim kemarau untuk mengantisipasi bencana banjir dan kekeringan serta disimpan pada tingkat record dan file. Informasi atribut yang digunakan meliputi number, string, dan date untuk menyajikan peta-peta tematik musim hujan dan kemarau untuk mengantisipasi bencana banjir dan kekeringan. Informasi number, string dan date digunakan untuk 12 komponen informasi spasial, yaitu : batas desa, batas kecamatan, batas kabupaten, batas provinsi, stasiun curah hujan, badan air, catchment area, isohyet, isobar, isotemp, wind roses dan land use.

\section{KESIMPULAN DAN SARAN}

\section{Kesimpulan}

- Model konseptual yang dihasilkan memudahkan peneliti memilah komponen-komponen informasi keruangan (grafis dan tekstual) yang harus dikumpulkan dan dikonversi dari data analog menjadi data digital.

- Model fungsional yang dihasilkan mempermudah para operator memilih jenis-jenis informasi keruangan (grafis 
dan atribut) yang akan digunakan untuk setiap komponen informasi keruangan.

- Model implementasi yang dihasilkan mempermudah para pembuat program menghasilkan system informasi keruangan musim hujan dan kemarau untuk mengantisispasi bencana bajir dan kekeringan terkait dengan nama file, jenis informasi (grafis dan atribut) serta tempat penyimpanan informasi.

\section{Saran}

- SOP dan flow chart untuk perancangan model konseptual perlu dibuat untuk membantu para pelaksana dalam menghasilkan model konseptual yang tepat guna dan berhasil guna.

- SOP dan flow chart untuk menghasilkan model fungsional yang mampu mengakomodasi model konseptual harus dibuat agar model fungsional konsisten dengan model konseptualnya serta tidak menyimpang terhadap rambu-rambu model konseptualnya.

- Manual implementasi penyajian informasi keruangan musim hujan dan kemarau untuk mengantisipasi bencana banjir dan kekeringan perlu disosialisasikan kepada para pelaksana pengembang system informasi keruangan yang mengacu pada model konseptual dan model fungsionalnya.

\section{DAFTAR PUSTAKA}

Alisjahbana, A.S. 2014. Rencana Aksi Nasional Adaptasi Perubahan Iklim. Kementerian Perencanaan Pembangunan Nasional / Badan Perencanaan Pembangunan Nasional. Jakarta.

As-syakur, A.R., I.W. Nuarsa dan I.N. Sumarta. 2011. Pemutakhiran Peta Agroklimat Klasifikasi Oldeman di Pulau Lombok dengan Aplikasi Sistem Informasi Geografi. Prosiding Penelitian Masalah Lingkungan di Indonesia 2010: 79-87. Universitas Udayana. Bali.

Craglia, M., M.F.Goodchild, A. Annoni, G. Camara, M. Gould, W. Kuhn, D. Mark, I. Masser, D. Maguire, S. Liang and E. Parsons. 2008. Next-Generation Digital Earth. A position paper from the Vespucci Iniative for the Advancement of Geographic Information Science.
International Journal of Spatial Data Infrastructures Research. Volume 3. 146-167. DOI: $10.2902 / 1725-$ 0463.2008.03.art9.

Dobrowski, S.Z., J.T. Abatzoglou, J.A. Greenberg and S.G. Schladow. 2009. How much influence does landscapescale physiography have on air temperature in a mountain environment ?. International Journal of Agricultural and Forest Meteorology 149 (2009) 1751-1758. C 2009 Elsevier B.V. All rights reserved. Doi:10.1016/j.agroformet.2009.06.006.

Lopez-Moreno, J.I., S. Goyette and M.Beniston. 2009. Impact of climate change on snowpack in the Pyrenees: Horizontal spatial variability and vertical gradients. Journal of Hydrology 374 (2009) 384-396. C 2009 Elsevier $\mathrm{B}, \mathrm{V}, \quad$ All rights reserved. Doi:10.1016/j.jhydrol.2009.06.049.

Montecinos, S., L.Bascunan-Godoy, P. Salinas, O. Astudillo and D. Lopez. 2013. Estimating Spatial Distribution of Air Temperature from Meteorological Stations Using Atmospheric Model. Journal of Agricultural Science; Volume 5, No 2; 2013. ISSN 1916-9752 E-ISSN 1916-9760. Published by Canadian Center of Science and Education.

Wijayanto, Y. 2013. Kajian Penggunaan Sistem Informasi Geografis (SIG) untuk Pertanian Presisi. Fakultas Pertanian Universitas Jember.

Willmott, C.J., and K. Matssura. 2006. On the use of dimensioned measures of error to evaluate the performance of spatial interpolators. International Journal of Geographical Information Science Volume 20, No 1, January 2006, 89-102. ISSN 1365-8816 print/ ISSN 1362-3087 online c 2006 Taylor \& Francis.DOI:10.1080/136588105002869 76. 